\title{
Customer Satisfaction \& Loyalty and Organizational Complaint Handling: Economic Aspects of Business Operation of Airline Industry
}

\author{
Rizwan Raheem Ahmed ${ }^{1}$, Jolita Vveinhardt ${ }^{2}$, Usman Ali Warraich ${ }^{3}$, Syed Shabib ul Hasan ${ }^{4}$, \\ Akhtar Baloch ${ }^{5}$
}

\author{
${ }^{1}$ Indus University \\ Block-17, Gulshan, Karachi, Pakistan \\ E-mail.rizwanraheemahmed@gmail.com \\ ${ }^{2}$ Vytautas Magnus University \\ K. Donelaicio g. 58, 44248 Kaunas, Lithuania \\ E-mail.jolita.vveinhardt@vdu.lt \\ ${ }^{3}$ Indus University \\ Block-17, Gulshan, Karachi, Pakistan \\ E-mail.Warraich.U.A@gmail.com \\ ${ }^{4,5}$ University of Karachi \\ Main University Road, Karachi, Pakistan \\ E-mail. ${ }^{4}$ Sshassan@uok.edu.pk, ${ }^{5}$ abaloch@uok.edu.pk
}

cross $^{\text {ref }}$ http://dx.doi.org/10.5755/j01.ee.31.1.8290

\begin{abstract}
The undertaken study examines economic aspects of business operations of the airline industry vis-à-vis organizational complaint handling and customer loyalty. For this purpose, we used a structured questionnaire to collect sample data of 200 respondents from university students and households of Pakistan who are the customers of the airline industry. We employed five independent variables, namely, response time, complaint resolution perfection, executives' attitude, brand image and responsiveness to complaints. We used the descriptive analysis and SEM-based approaches; namely, confirmatory and exploratory factor analysis for estimation purposes. The findings of the undertaken study demonstrated that the resolution of complaints, timely response, and responsiveness to complaints had a significant and positive influence on satisfaction of customers and loyalty of clients using international airline services, and this leads to the economic prospects of business operation in the airline industry. However, customer relationship, executives' attitude and brand loyalty do not have significant influence on the customer satisfaction and customer loyalty. Thus, it is concluded that the immediate response to customer complaint handling enhances the customer satisfaction and customer loyalty that increases the economic aspects of business operation in the airline industry.
\end{abstract}

Keywords: Organizational Complaints; Customer Loyalty; Resolution Perfection; Complaint Handling; Customer Satisfaction.

\section{Introduction}

The airline industry has always been categorised as one of the major intangible services provider industries (Kloppenborg \& Gourdin, 1992; Homburg \& Furst, 2005). According to Heymann (2019), Lee (2017), and Clemes et al. (2000), this categorisation pertains to five distinguishing hallmarks of services. The economic aspects of the services sector not only provide new business opportunities but also face competitive threats from other services industries, and the airline industry particularly takes on several challenges from other services industries. Traditionally, the governments were involved in the regulation of the airline industry due to one of the major economic aspects across the globe (Augusto et al., 2019; Etemad-Sajadi \& Bohrer, 2019). However, since 1978, the US has passed the airline regulation act that transformed the global airline businesses into the competitive structure because the US deregulation has been part of greater global airline liberalization trend, specifically for the European Union, Latin America, and Asia (Metwally, 2013). After the deregulation, the airline industry was allowed to make certain changes in price setting, the measures of insurance and safety; thus, this revolution brought positive changes in the economic aspects of the airline industry. The new airlines have stepped in and competition has increased, but at the same time, service quality and customer satisfaction became an integral part of the airline industry (Dudek et al., 2019; Dennett et al., 2000; Vilkaite-Vaitone \& Papsiene, 2016). According to Karamata et al. (2017), Ostrowski et al. (1993), and Lee and Cunningham (1996), due to intense competition, airline companies started to offer different promotional campaigns such as frequent flyer programs and computerized reservation services in order to retain customers, long-term customer loyalty and economic growth.

Time became a focal and decisive factor enabling the transfer of people and goods from one place to another through the airlines locally and internationally for any country. Every year, significant economic growth has been observed in both passenger and freight services (Law, 2017). On the other hand, the airline industry is growing at a phenomenal rate, new airlines are stepping in, and old organizations increase their aircraft numbers, new airport 
facilities have been expanding day by day. Thus, in this scenario, there is an intense competition in the airline industry in terms of the economic aspects of business operation and competitive growth (Clemes et al., 2008; Etemad-Sajadi \& Bohrer, 2019). Like in other service industries, the customer is a focal point; it is essential to make them satisfied and happy in order to retain customers for the repeat business (Alrawadieh et al., 2019; Prentice et al., 2017). Similarly, due to transnational trade and economic aspects, the freight business is also growing; thus, organizations are also prime customers for the airline industry and compel it to look for ways to keep them satisfied with competitive services. The customer satisfaction becomes more vital when the airline industry provides intangible services; the core business area of this industry belongs to the transportation of people and goods from one place to another (Chow \& Tsui, 2017). The airline industry is unique in a way that it faces the competition within and outside the industry, and other than airline industry. Thus, the airline industry has more severe competition as compared to other service industries. Hence, this intense competition has increased the challenges to the airline industry (Augusto et al., 2019; Dwikesumasari \& Ervianty, 2017). The transportation of people and goods from one place to another is of vital importance; thus, the airline industry is categorized as more intangible service business (Law, 2017; Daetz et al., 1995). According to Ostrowski et al. (1993), and Iriqat and Abu-Daqar (2017), the growth in services sectors opens new avenues of economic aspects and business opportunities, which also provides competitive threats to other services organizations, and this is true for the airline industry. Generally, in the airline industry, customers have a 'direct contact mode'; therefore, the customer relations in the airline industry have more significance as compared to any other service industry (Smirnov, 2019; Cambra-Fierro \& Melero-Polo, 2017). Customer expectations have increased and they have become more demanding. This increases the importance of continuous assessment to define elements that satisfy customer needs and increase the future economic aspects. Handling customer complaints is one of the crucial elements to retain customers (Chen \& Jai, 2019; Dwikesumasari \& Ervianty, 2017; Iriqat \& Abu-Daqar, 2017). A specific consideration is given to analyse customer complaints, due to the specific activities related to customer experiences during the traveling. Airline companies seek to resolve economic aspects of business problems that are encountered as a result of the world economic crisis causing the bankruptcy of small companies or due to accidents (Karamata et al., 2017; Oyewole et al., 2007). The results of the previous literature exhibited that organizations that experienced higher customer loyalty were more likely to respond positively to customer complaints (Law, 2017; Estelami, 2000; Fullerton, 2003). The majority of the researchers such as Prentice et al. (2017), Davidow (2003), Karande and Magnini (2010), Chan (2014), and So et al. (2014) pointed out interrelated connection among the complaints, response time, quality of response, customer loyalty, company image, and economic aspects. However, more questions still remain to be answered aiming to conjoin resolution perfection, complaint handling, customer satisfaction, customer loyalty and other factors that form a precondition of improving the performance, and economic growth of airline companies.
The significance of the airline industry has increased several times in the last few decades due to globalization that increases the opportunities of economic aspects of business operation, tourism, education, workforce migration, and immigration for skilled and non-skilled workers, freight and courier services. Time has become a focal and decisive factor; therefore, people and goods are transferred from one place to another place through the airlines locally and internationally to any country (Alrawadieh et al., 2019; Chow \& Tsui, 2017; Clemes et al., 2008). Every year, a significant growth has been observed in both passengers and freight services. Moreover, due to significant economic aspects, the airline industry is growing at a phenomenal rate, new airlines are stepping in, and old organizations increase their aircraft numbers, new airport facilities have been expanding day by day (Augusto et al., 2019). Thus, in this scenario, there is an intense competition within the airline industry (CambraFierro \& Melero-Polo, 2017). Therefore, there was an utmost need to address the factors that may increase the customer loyalty and economic aspects of the airline industry. According to Yao et al. (2019), Law (2017), Vilkaite-Vaitone and Papsiene (2017), Ostrowski et al. (1993), the positive image of the organization can be built through long-term services and affirmative handling of customer complaints.

The outcomes of the undertaken study are value addition and significant contribution to the existing literature regarding customer complaint handling determinants, customer satisfaction, and new economic aspects of business operation in the perspective of the airline industry. However, the novelty of the undertaken study lies in a thematic scope, which introduces a unique model that is based on five factors such as response time, complaint resolution, executive attitude, the brand image and the response to complaint handling. In this research, we used SEM-based modelling, for instance, confirmatory factor analysis and exploratory factor analysis. The model is unique in the sense that we incorporated new constructs and dimensions. We examined the validities and reliabilities of new constructs, which will be a valuable addition for the future studies.

The new millennium has brought a paradigm shift in consumer behaviour, and consumer expectations have been increasing, which poses serious challenges in the airline industry. Customers have numerous opportunities for brand switching; therefore, there is an utmost need for timely response to customer complaints in order to attain their loyalty. If customers are ignored and their problem is not addressed, they would not only be dejected but would also change the airline brand, which will cause a severe damage to the airline in terms of customer loyalty and economic aspects of business operation (Dudek et al., 2019; Clemes et al., 2008). Thus, it is high time to the airline industry to come up with concrete strategies to resolve customer complaints in order to retain customer satisfaction and loyalty. Hence, in this scenario, there is a strong need to study the factors of customer complaint handling and their impact on the customer satisfaction, loyalty, and future economic aspects of business operation of the airline industry.

The objective of the undertaken study is to examine the customer complaint handling and its impact on customer satisfaction, customer loyalty, and economic aspects in the airline industry. Another aim of this research is to investigate the determinants of customer satisfaction that 
lead to customer loyalty in case of the airline industry. The outcomes of the undertaken study will provide an opportunity for other researchers to replicate these factors for other services sectors. Currently customer satisfaction is an essential element to gain customers' trust and loyalty that ensure customer retention and repeat purchase opportunities in an intensely competitive environment, which leads to the new economic aspects for the airline industry. Thus, the outcomes of this study also provide the guidelines to policymakers and senior managers of the airline industry to come up with novel strategies to attain customer satisfaction and loyalty, which will deliver augmented economic aspects of business opportunities for optimum profitability. The results of the study also offer the basis to the regulatory bodies to formulate and implement regulations that will be beneficial to both customers and the airline industry.

\section{Previous Literature and Hypotheses Formulation}

\section{Customer Satisfaction}

The most studied area in the field of marketing is the customer satisfaction due to its important and direct linkage with economic aspects of business operation, the companies' objectives and profitability; moreover, the customer satisfaction is the benchmark of quality standard and excellence for any organization (Karamata et al., 2017; Oyewole et al., 2007). According to Heymann (2019), Law (2017), and Fecikova (2004), the slogan "the customer is always right" is a true depiction of customers' importance and priority. Thus, companies always strive to retain existing customers through motivation and satisfaction, and those satisfied customers could bring new customers through positive word of mouth (Yao et al., 2019; Wever, 2016). According to Iriqat and Abu-Daqar (2017) and Zeelenberg and Pieters (2004), in the airline industry, the customer satisfaction is important due to intense competition: the satisfied customer is a source of brand loyalty, while the dissatisfied customer, on the contrary, will not only switch to another brand but also be the source of negative word of mouth. Now, the digital media communication spreads sentiments of satisfied or dissatisfied customers rapidly, whether negative or positive; hence, the customer satisfaction brings new customers and increases profitability, whereas the dissatisfied customers destroy the image of the organization and affect the reputation, and economic aspects of business (Chen \& Jai, 2019; Prentice et al., 2017; Fornell et al., 1996; Shin \& Elliott, 2001).

\section{Service Quality in the Airline Industry and Customer Satisfaction}

According to Vilkaite-Vaitone and Papsiene (2016), Law (2017), satisfaction is an instant reaction of service consumption; however, the service quality is inferred as the holistic image of a company in the mind of customers with regard to the airline industry. The perceived value and expected service influence the service quality. According to Parasuraman et al. (1985), if customers received the expected quality of services, they would be satisfied, if they received more than they expected, they would be delighted and would perceive the service quality as excellent. Like in other service sectors, the significance of customer satisfaction is extracted from the usually accepted philosophy that the satisfied customer is a source of successful future economic aspects and profitable business (Karamata et al., 2017; Shin \& Elliott, 2001). According to previous literature regarding customer satisfaction in the airline industry, such as Lee (2017), Cronin and Taylor (1992), and Fornell et al. (1996), repeat purchase intentions are strongly connected with the customer satisfaction. According to Moon et al. (2019), and Fornell (1992), the customer satisfaction also acts as an exit barrier and supports the organization to retain its existing customers in order to safeguard future economic aspects. The previous literature showed that the new customer capturing was more costly as compared to retaining existing customers in the airline industry (Alrawadieh et al., 2019; Lee, 2017; Gummesson, 1994; Blodgett et al., 1995).

\section{The Response Time of Customer Handling and Customer Satisfaction}

Timeliness is one of the recovery strategies that have an imperative function in fixing a problem of a failed service, especially in the airline industry (Law, 2017). Timeliness in correcting the problem is necessary for the successful service recovery (Lee, 2017; Wirtz \& Mattila, 2004). Research has shown that customers can accept failures but will not forgive the organization when they cannot fix the problem within the stipulated time period (Mattila, 2006). According to Karamata et al. (2017), and Davidow (2003), speedy reply to the customer complaint cuts back the amount of negative word of mouth in perspective of the airline industry. Thus, service quality improvement depends on the ability of the airline to regularly meet passenger needs and desires and address their complaints promptly (Dudek et al., 2019; Prentice et al., 2017). By resolving customer complaints without a delay, the airline can benefit in order to achieve the competitive advantage, which enhances the service quality that would lead to the customer satisfaction and future economic aspects (Law, 2017). In return, the airline company gets several benefits from customers, such as: strong relationship with customers, repurchase activities, enhanced customer loyalty, advantage of positive word of mouth, good corporate image, and, ultimately, increased airline profitability, and future economic aspects of business operation (Lee, 2017; Wever, 2016; Park et al., 2005, 2006). Consequently, the airlines must recognize the prominence of complaint handling and respond immediately, which is of strategic importance for customer satisfaction. Customer satisfaction through immediate handling of customer complaints, loyalty of customers will be enhanced, which will be fruitful to retain existing customers and attract potential customers through positive word of mouth (Yao et al., 2019; Etemad-Sajadi \& Bohrer, 2019; Oyewole et al., 2007; Fornell, 1992). Numerous studies have demonstrated that the immediate response time to respond to customer complaints not only retains the existing customer but also brings a new customer (Dudek et al., 2019; Prentice et al., 2017; Blodgett et al., 1995; Gummesson, 1994). Hence, based on the previous literature, we have formulated the following hypothesis:

H1: Response time of customer complaint handling has a significant and positive impact on customer satisfaction in the case of the airline industry. 


\section{Complaint Resolution Perfection and Customer Satisfaction}

Resolution of customer complaints in an effective and perfect way should be considered as feedback and opportunity to retain customers in the case of the airline industry (Michel, 2001; Karamata et al., 2017). The efficient management system of complaints handling is an imperative factor encouraging customers to register the complaint, and at the organization level, the speedy system to resolve complaints in a professional way provides primary satisfaction to customers (Law, 2017; Lee, 2017). Proper and professional handling of customer complaints can increase the customer retention and also bring new customers through positive word of mouth; similarly, the recovery efforts of the airline may enhance the customer loyalty and future economic aspects in terms of new business (Vilkaite-Vaitone \& Papsiene, 2016; Smith et al., 1999). According to Moon et al. (2019), Wever (2016), and Goodwin and Ross (1992), service recovery efforts enhance the customer satisfaction, but in contrast, the organization's insufficient response to complaint handling not only irritates the existing customers but also leads to customer switching to another airline due to negative word of mouth. Thus, the effect of the aforementioned antecedent such as complaint resolution perfection is a significant element for sustainability and satisfaction of customers and new economic prospects of business operation in the airline industry (Alrawadieh et al., 2019; Cambra-Fierro \& MeleroPolo, 2017; Law, 2017). Hence, we have formulated the following hypothesis on the basis of previous literature:

H2: The complaint resolution perfection of customer complaints handling has a significant and positive impact on customer satisfaction in the case of the airline industry.

\section{Customer Relations \& Executives' attitude and Customer Satisfaction}

Companies' performance also depends on the attitude of senior management; executives' attitude not only determines the conduct of other employees but also has a significant impact on profitability and future economic aspects of business operation of the airline company (Law, 2017; Metwally, 2013). Thus, customer relations are indirectly influenced by the executives' attitude, which ultimately influences customer satisfaction (Augusto et al., 2019; Prentice et al., 2017; Fornell et al., 1996). According to Metwally (2013), the commitment building starts from the top and then trickles down to the lower level of management. According to Metwally (2013), customer complaint handling and customer satisfaction can be achieved by making it part of their business and marketing plans. The executives should regularly review the reports on complaint handling and the recruitment of suitable human resources well versed in customer complaint handling (Blodgett et al., 1995). According to Iriqat and Abu-Daqar (2017), and Zeelenberg and Piters (2004), top management should implement the system of incentives to those employees who were exceptional in making an effective response to customer complaints. The management role is very crucial because written policies always come from the top; thus, the executives' role is paramount to implement and review policies and provide an effective communication environment to resolve customer complaints. As a result, all these efforts establish good relationships with customers, enabling the organization to attain the customer satisfaction, which may lead to the customer loyalty and future economic aspects of business operation (Chen \& Jai, 2019; Lee, 2017; Etemad-Sajadi \& Bohrer, 2019). Hence, based on the previous literature, we have formulated the following hypothesis:

H3: Customer relations \& executives' attitude have a significant and positive impact on the customer satisfaction in the case of the airline industry.

\section{Brand Image and Customer Satisfaction}

The airline company that has a positive brand image is likely to stay in the market, retain existing customers and attract new customers, and successfully compete with its competitors (Connor \& Davidson, 1997). According to Iriqat and Abu-Daqar (2017), the corporate/brand image of the organization could be explained as: "the perceptions of an organization reflected in the associations held in consumers' memory, which distinguishes the organization from other competitors". Trust and reliability trigger the brand image and since there is intense competition in the airline industry, the brand image plays a significant role in attracting new customers for future economic aspect and attaining competitors' advantage amongst competitors (Dwikesumasari \& Ervianty, 2017; Nguyen \& LeBlance, 2001). Thus, the brand image of the airline company has a distinctive role in trust building amongst passengers, which propels the customer loyalty (Andreassen \& Lindestad, 1998), repeat patronage, and customer retention (Lee, 2017; Nguyen \& LeBlance, 2001). According to Chow and Tsui (2017), Wu (2011), and Johnson et al. (2001), numerous studies have specified that the brand image is one of the most important elements to gain the customer satisfaction leading to the customer loyalty and future economic aspects of business operation in the perspective of the airline industry (Dennett et al., 2000). Thus, it is concluded from the previous literature pertaining to the airline industry that the brand image is one of significant elements, which influences the customer expectations, customer satisfaction, and customer loyalty (Servera-Frances \& Piqueras-Tomas, 2019; Law, 2017; Cambra-Fierro \& Melero-Polo, 2017). Hence, the following hypothesis is formulated on the basis of previous literature:

H4: the brand image of the organization has a significant and positive impact on customer satisfaction in the case of the airline industry.

\section{Responsiveness to Complaints and Customer Satisfaction}

According to Homburg and Furst (2005), the quality service, responsiveness to complaint handling, and the effective system of complaints resolution drive the customer satisfaction and loyalty in the airline industry. The similar conclusion has been attained in several other studies that responsiveness to complaint handling is a major factor for the customer satisfaction in case of the airline industry (EtemadSajadi \& Bohrer, 2019; Lee, 2017). Numerous studies have demonstrated that responsiveness to complaints brought the 
customer closer, satisfied the customer, and that the satisfied customer led to the increase of such economic aspects as business operations, sales, growth, and profits of the airline industry (Karamata et al., 2017; Dwikesumasari \& Ervianty, 2017; Dennett et al., 2000). However, the higher level of service quality bring the customer loyalty and that service quality can be delivered through hospitality and responsiveness to customer complaint handling at the right time (Servera-Frances \& Piqueras-Tomas, 2019; Lee, 2017; Metwally, 2013). As the study of the airline industry reveals, the response to the customer complaints is one of the major elements leading to the customer satisfaction and customer loyalty that can enhance the economic aspects of business operation in terms of profitability and competitive advantage of the organization (Gomez et al., 2006; Chow \& Tsui, 2017). Prentice et al. (2017) have carried out an important study in which they incorporated the response rate of customer complaints and concluded that, besides other factors, the responsiveness to complaints have significant positive influence on the customer satisfaction that leads to the customer loyalty (Moon et al., 2019). Hence, we have formulated the following hypothesis on the basis of previous literature:

H5: Responsiveness to complaints has a significant and positive influence on the customer satisfaction in the case of the airline industry.

\section{Customer Satisfaction and Customer Loyalty}

Loyalty can be described as the vow and commitment of an individual to buy any particular service or product every time (Oliver, 1997; Lee, 2017). In general, consumers change their behaviour or change brands on the basis of different elements, but customers change their loyalty only on the basis of the brand specification; thus, loyalty can be considered as promotion regardless of relationship of marketing factors (Dudek et al., 2019; Metwally, 2013). The most critical and important subject for the profit-based organization is the customer satisfaction that leads to the customer loyalty and future economic aspects of business operation (Zeithaml, 2000; Dennett et al., 2000). According to Karamata et al. (2017), and Majumdar (2005), the customer retention and loyalty can only be possible if the customer is satisfied, and ultimately, the airline company would generate augmented profits and future economic prospects. Thus, based on previous studies, such as Chen and Jai (2019), Cronin and Taylor (1992), Dwikesumasari and Ervianty (2017), and Fornell (1992), it is concluded that retention and loyalty of existing customers are the key factor for the success of the airline industry. According to Blodgett et al. (1995), and Chow and Tsui (2017), the customer satisfaction and customer loyalty are interchangeable in high quality service organizations; moreover, the customer satisfaction leads to the customer loyalty through positive word of mouth in the airline industry. Hence, we have formulated the following hypothesis on the basis of previous literature:

H6: The customer satisfaction exerts a significant and positive impact on the customer loyalty in the case of the airline industry.

\section{The Theoretical \& Conceptual Model}

We have used adapted and modified theoretical \& conceptual research model as exhibited in Figure 1; however, most of the factors and items were taken from the previous literature (Metwally, 2013; Chan, 2014; So et al., 2014).

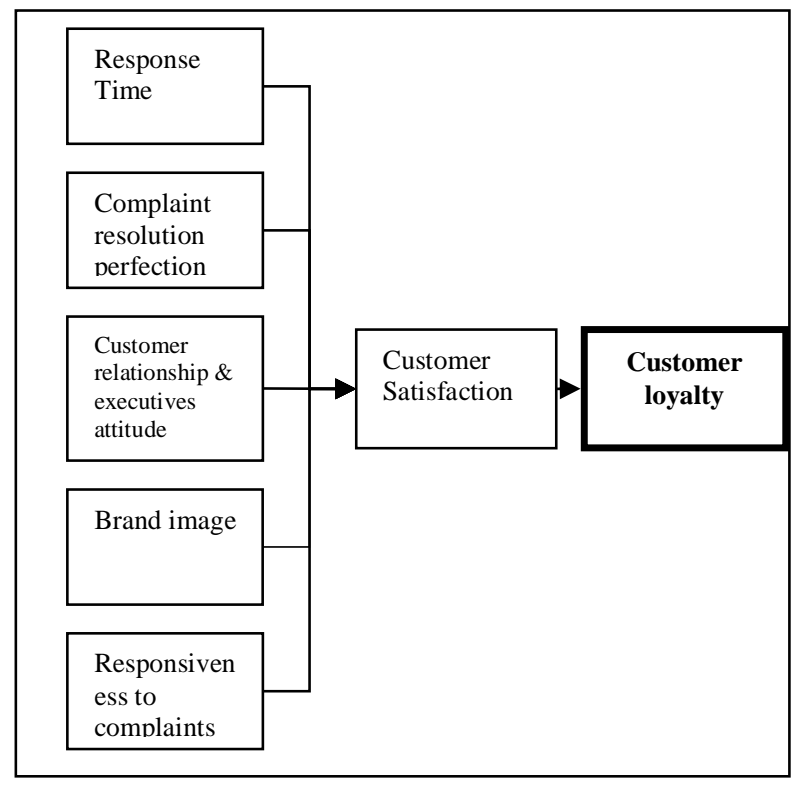

Figure 1. The Theoretical Framework of the Research Model

\section{Material and Methods}

\section{The Sampling Strategy and Sample Size}

We have taken the sample data from the target universities and general public respondents from households. The overall sampling frame is undefined; therefore, we used the non-probability sampling technique, such as the purposive sampling technique, which is the right choice to get the responses. The responses are gathered from the students of the universities and general public who have the experience of traveling by air; therefore, we used the purposive sampling technique. The sample size was 200; however, we have distributed 230 questionnaires to the target population. Thirty respondents did not respond and provided inadequate responses, thus, we have included 200 responses for the undertaken study.

\section{The Instrument of Data Collection}

We have used adapted and modified questionnaire from the previous literature (Metwally, 2013; Chan, 2014; So et al., 2014). We have used four constructs for each independent variable such as response time, complaint resolution perfection, brand image, and responsiveness to complaints, except for customer relations and executives' attitude, in which we used three items. Moreover, we have used four items for each customer satisfaction and customer loyalty. We have used a structured questionnaire with fivepoint Likert scales as an instrument to gather the responses.

\section{Statistical Tool \& Respondents' Profile}

We have employed exploratory factor analysis, descriptive analysis, and confirmatory factor analysis in order 
Rizwan Raheem Ahmed, Jolita Vveinhardt, Usman Ali Warraich, Syed Shabib ul Hasan, Akhtar Baloch. Customer Satisfaction...

to examine the sample data. As far as the demographic profile of the respondents is concerned, there were 102(51.0\%) males, and $98(49.0 \%)$ females, in which $117(58.5 \%)$ respondents were single, $77(38.5 \%)$ were married, however, 6(3.0\%) respondents were divorced. In terms of age, we selected respondents from 18-60 years, and the respondents' qualification ranged from the high school diploma to postgraduate degrees. As far as experience is concerned, the respondents have 5-20 years of experience, and, finally, their income bracket lies between 10 to 90 thousand Pakistan Rupee.

\section{Estimations and Results}

\section{Descriptive Analysis}

The outcomes of Table 1 confirm the normality pattern of the data; for this purpose, we transformed data into $\mathrm{z}$ scores and employed the descriptive analysis. The results demonstrated that values of skewness and standard deviation lie between \pm 1.5 , and values of kurtosis range between \pm 3 ; hence, the normality of the collected data is evident (Ahmed et al., 2019; Byrne, 2013).

\section{Reliabilities and AVE Analysis}

The outcomes of Table 2 exhibit that measure of composite reliabilities and Cronbach's alpha are more than 0.80 , which meets the minimum criterion of 0.60 (Ahmed et al., 2019; Hair et al., 2010). The values of all the factors loadings (FL) that have been extracted through the rotated component matrix (Principal component analysis) are more than 0.50 , which also meets the criterion of discriminant validities. Moreover, the results of average variance extracted (AVE) are more than 0.50, which fulfils the criterion of convergent validities, which is a prerequisite for employing the exploratory and confirmatory factor analysis (Fornell \& Larcker, 1981).

Descriptive Analysis

\begin{tabular}{|c|c|c|c|c|c|c|}
\hline \multirow{2}{*}{ Variables } & \multirow{2}{*}{$\begin{array}{c}\text { Mean } \\
\text { Statistic }\end{array}$} & \multirow{2}{*}{$\begin{array}{c}\text { Std. Deviation } \\
\text { Statistic }\end{array}$} & \multicolumn{2}{|c|}{$\begin{array}{c}\text { Skewness } \\
\end{array}$} & \multicolumn{2}{|c|}{ Kurtosis } \\
\hline & & & Statistic & Std. Error & Statistic & Std. Error \\
\hline Response time & 3.79 & 1.045 & -.772 & .172 & .131 & .342 \\
\hline Complaint resolution perfection & 3.98 & 1.063 & -.913 & .172 & .306 & .342 \\
\hline Responsiveness to complaint & 3.91 & .944 & -.896 & .172 & 1.141 & .342 \\
\hline $\begin{array}{l}\text { Customer relations \& executives } \\
\text { attitude }\end{array}$ & 3.95 & 1.071 & -.930 & .172 & .380 & .342 \\
\hline Customer satisfaction & 3.94 & 1.037 & -.906 & .172 & .450 & .342 \\
\hline Brand image & 3.41 & 1.117 & -.415 & .172 & -.649 & .342 \\
\hline Brand loyalty & 3.78 & 1.013 & -.776 & .172 & .444 & .342 \\
\hline
\end{tabular}

Source: Authors' calculations

Table 2

Reliabilities and Average Variance Extracted

\begin{tabular}{|c|c|c|c|c|c|}
\hline Variables & Constructs & FL & $\mathbf{C A}$ & CR & AVE \\
\hline \multirow{4}{*}{ Customer satisfaction } & CS1 & .877 & \multirow{4}{*}{.867} & \multirow{4}{*}{.925} & \multirow{4}{*}{756} \\
\hline & $\mathrm{CS} 2$ & .903 & & & \\
\hline & CS3 & .896 & & & \\
\hline & CS4 & .798 & & & \\
\hline \multirow{4}{*}{ Response Time } & RT1 & .906 & \multirow{4}{*}{.821} & \multirow{4}{*}{.895} & \multirow{4}{*}{.685} \\
\hline & RT2 & .901 & & & \\
\hline & RT3 & .829 & & & \\
\hline & RT4 & 649 & & & \\
\hline \multirow{4}{*}{ Complaint resolution perfection } & CRP1 & .812 & \multirow{4}{*}{.793} & \multirow{4}{*}{.873} & \multirow{4}{*}{.635} \\
\hline & CRP2 & .905 & & & \\
\hline & CRP3 & .775 & & & \\
\hline & CRP4 & 679 & & & \\
\hline \multirow{4}{*}{ Responsiveness to complaint } & RTC1 & .790 & \multirow{4}{*}{.853} & \multirow{4}{*}{.914} & \multirow{4}{*}{.729} \\
\hline & RTC2 & .844 & & & \\
\hline & RTC3 & .901 & & & \\
\hline & RTC4 & .877 & & & \\
\hline \multirow{3}{*}{ Customer relations \& executives attitude } & CREA1 & .755 & \multirow{3}{*}{.800} & \multirow{3}{*}{.844} & \multirow{3}{*}{.645} \\
\hline & CREA2 & .890 & & & \\
\hline & CREA3 & .756 & & & \\
\hline \multirow{4}{*}{ Brand image } & BI1 & .912 & \multirow{4}{*}{.780} & \multirow{4}{*}{.868} & \multirow{4}{*}{.630} \\
\hline & BI2 & .768 & & & \\
\hline & $\mathrm{BI} 3$ & .899 & & & \\
\hline & BI4 & .540 & & & \\
\hline \multirow{4}{*}{ Customer loyalty } & CL1 & .789 & \multirow{4}{*}{.861} & \multirow{4}{*}{.920} & \multirow{4}{*}{.743} \\
\hline & CL2 & .867 & & & \\
\hline & CL3 & .887 & & & \\
\hline & CL4 & .901 & & & \\
\hline
\end{tabular}

Note: CS: Customer satisfaction; RT: Response time; CRP: Complaint resolution perfection; RTC: Responsiveness to complaint; EA: Executives attitude; BI: Brand image; CL: Customer loyalty

Source: Authors' calculations 


\section{Exploratory Factor Analysis - EFA}

For reduction and fitness purposes, we employed exploratory factor analysis. We have taken 7 factors and 27 constructs; according to Ahmed et al. (2019), and Emory and Cooper (1991), EFA is a proficient method to examine and shrink the sample data into a reduced form. For the undertaken study, we have considered customer satisfaction (CS) as a dependent variable that subsequently propels customer loyalty (CL). Both CS and CL factors have four constructs. Moreover, we have taken five independent variables, such as response time (RM), complaint resolution perfection (CRP), responsiveness to complaint (RTC), and brand image (BI) with four constructs, except customer relations \& executives attitude (CREA), which have three items in each variable to analyse the impact of predictors on the customer satisfaction, customer loyalty, and future economic aspects of business operation in the airline industry. The outcomes of rotated component matrix exhibit that factor loading of each pair of factor and variable is greater than 0.50 . Thus, the results demonstrated that our taken factors and items were valid, and we could proceed with further analysis (Hair et al., 2010; Kaiser, 1974).

\section{Kaiser Meyer Olkin (KMO) \& Bartlett's Techniques}

For the adequacy and fitness of the sample data, we employed the KMO analysis and Bartlett's Sphericity test. The outcomes of Table 3 exhibit that the value of KMO is 0.831 that is fairly excellent (Kaiser, 1974). The Bartlett's
Sphericity Test shows significant and adequate correlation between items because the probability is less than 0.05 .

Table 3

The KMO Analysis and Bartlett's Approach

\begin{tabular}{ll|r}
\hline Kaiser-Meyer-Olkin Measure of Sampling Adequacy. & .831 \\
\hline \multirow{3}{*}{ Bartlett's Test of Sphericity } & Approx. Chi-Square & 1470.290 \\
& $\mathrm{Df}$ & 21 \\
& $\mathrm{Sig}$. & .000 \\
\hline
\end{tabular}

Source: Authors' calculations

\section{Total Variance Explained}

The outcomes of Table 4 exhibit that total variance explained that is the cumulative percentile variance $(80.41 \%)$ of seven factors, which is considered to be very good. Moreover, the Eigenvalue of each factor is greater than 1, which further substantiated the amount of variance amongst the potential factor. Thus, on the basis of cumulative variance and Eigenvalues, it is established that our sample data is reliable and we can proceed for further exploration.

\section{Ant-Image Correlation Matrix}

For the de-selection and validation of factors, we employed the anti-image correlation matrix (AICM) approach. On the diagonal of AICM the individual factors' measures of sampling adequacy (MSA) is greater than 0.50 as exhibited in Table 5; thus, all our taken factors are validated, and now, we can retain all the factors to conduct our research.

Table 4

Total Variance Explained

\begin{tabular}{|c|c|c|c|c|c|c|c|c|c|}
\hline \multirow[b]{2}{*}{ Component } & \multicolumn{3}{|c|}{ Initial Eigenvalues } & \multicolumn{3}{|c|}{ Extraction Sums of Squared Loadings } & \multicolumn{3}{|c|}{ Rotation Sums of Squared Loadings } \\
\hline & Total & $\begin{array}{c}\% \text { of } \\
\text { Variance }\end{array}$ & Cumulative \% & Total & $\begin{array}{c}\% \text { of } \\
\text { Variance }\end{array}$ & $\begin{array}{c}\text { Cumulative } \\
\%\end{array}$ & Total & $\begin{array}{c}\% \text { of } \\
\text { Variance }\end{array}$ & Cumulative \% \\
\hline 1 & 15.070 & 51.964 & 51.964 & 15.070 & 51.964 & 51.964 & 14.888 & 51.339 & 51.339 \\
\hline 2 & 1.797 & 6.196 & 58.160 & 1.797 & 6.196 & 58.160 & 1.589 & 5.480 & 56.819 \\
\hline 3 & 1.434 & 4.947 & 63.107 & 1.434 & 4.947 & 63.107 & 1.364 & 4.702 & 61.521 \\
\hline 4 & 1.224 & 4.221 & 67.328 & 1.224 & 4.221 & 67.328 & 1.343 & 4.632 & 66.153 \\
\hline 5 & 1.119 & 3.859 & 71.187 & 1.119 & 3.859 & 71.187 & 1.316 & 4.538 & 70.691 \\
\hline 6 & 1.089 & 3.584 & 74.771 & 1.089 & 3.584 & 74.771 & 1.183 & 4.080 & 74.771 \\
\hline 7 & 1.025 & 3.299 & 80.411 & 1.025 & 3.299 & 80.411 & 1.040 & 3.858 & 80.411 \\
\hline
\end{tabular}

Extraction Method: Principal Component Analysis.

Source: Authors' calculations

Anti-Image Correlation Matrix

\begin{tabular}{|c|c|c|c|c|c|c|c|c|}
\hline & & CS & RT & CRP & RTC & EA & BI & $\mathbf{C L}$ \\
\hline \multirow{7}{*}{$\begin{array}{l}\text { Anti-image } \\
\text { Correlation }\end{array}$} & Customer satisfaction & $.875^{a}$ & -.249 & -.595 & -.099 & .032 & .012 & -.220 \\
\hline & Response time & -.249 & $.794^{\mathrm{a}}$ & .397 & -.405 & -.480 & -.422 & .227 \\
\hline & Complaint resolution perfection & -.595 & .397 & $.749^{a}$ & -.107 & -.514 & -.366 & .399 \\
\hline & Responsiveness to complaint & -.099 & -.405 & -.107 & $.915^{\mathrm{a}}$ & .095 & -.230 & -.197 \\
\hline & $\begin{array}{l}\text { Customers' relations \& executives } \\
\text { attitude }\end{array}$ & .032 & -.480 & -.514 & .095 & $.853^{\mathrm{a}}$ & .074 & -.215 \\
\hline & Brand image & .012 & -.422 & -.366 & -.230 & .074 & $.898^{a}$ & -.127 \\
\hline & Customer loyalty & -.220 & .227 & .399 & -.197 & -.215 & -.127 & $.794^{\mathrm{a}}$ \\
\hline
\end{tabular}

\section{Confirmatory Factor Analysis - CFA}

The CFA analysis is the useful direct approach for the SEM-based model to check the measurement model and fitness of sample data in a hypothesized measurement model
(Ahmed et al., 2019; Hair et al., 2010). In our hypothesized measurement model, it is confirmed that the factors for customer satisfaction (CS) and customer loyalty are response time (RT), complaint resolution perfection (CRP), responsiveness to the complaint (RTC), executives' attitude 
(EA), and brand image (BI). We have taken seven factors and 27 items with four items for each factor, except executive attitude (EA) that has three items, and fixed the data sample into observed and unobserved variables (Byrne, 2013). Since the factor loading of all the items ranges between $0.75-0.90$, this confirms that the overall measurement model is acceptable; moreover, the factor loadings of all the variables are more than 0.50 , which substantiates the convergent validities of all the construct of our hypothesized measurement mode. The results of Table 6 exhibit the fit indices of our measurement model, which shows that all the fit-indices follow the threshold values (IFI: 0.952, NFI: 0.912, CFI: 0.934, PNFI: 0.702, PCFI: 0.734, GFI: 0.928, and AGFI: 0.902).

\section{Hypothesized Direct Relationship}

For checking our hypothesized relationship, we employed standardized regression weights. The results of Table 7 demonstrated that our hypotheses H1, H2, H3, and H6 were substantiated because $(\mathrm{T}>2)$ and corresponding probabilities $(\mathrm{p}<0.05)$; however, $\mathrm{H} 4$ and $\mathrm{H} 5$ are not supported. Thus, it is concluded that response time, complaint resolution perfection, and responsiveness to the complaint have a significant and positive influence on the customer satisfaction that leads to the significant and positive influence on the customer loyalty. However, customer relations \& executives' attitude and brand image do not exert a cogent impact on the customer satisfaction. Though, individual results exhibited that the customer satisfaction had the highest impact (0.780) on the customer loyalty. The response time has the influence of 0.439 on the customer satisfaction followed by complaint resolution perfection with the impact of 0.424 on the customer satisfaction.

Table 6

Model Fit Indices

\begin{tabular}{c|c|c|c|c|c|c|c|c|c}
\hline Categories & \multicolumn{4}{|c|}{ Absolute } & \multicolumn{3}{c|}{ Relative } & \multicolumn{2}{c}{ Parsimonious } \\
\hline Fit Indices & $\chi^{2}$ & $\chi 2 / \mathrm{df}$ & GFI & AGFI & CFI & NFI & IFI & PNFI & PCFI \\
\hline Criteria & Low & $<5.0$ & $>0.90$ & $>0.90$ & $>9.0$ & $>0.9$ & $>0.95$ & $>0.50$ & $>0.50$ \\
\hline Values & 102.30 & 3.00 & 0.928 & 0.902 & 0.934 & 0.912 & 0.952 & 0.702 & 0.734 \\
\hline
\end{tabular}

Note. CFI: Comparative fit index; NFI: Normed fixed index; IFI: Incremental fixed index; PNFI: Parsimony adjusted normed fixed index; PCFI: Parsimonious adjusted fit index; GFI: Goodness of fit index; AGFI: Absolute goodness of fit index Source: Authors' calculations

Hypothesized Direct Relationship

\begin{tabular}{|c|c|c|c|c|c|c|c|}
\hline Hypothesis & Variables & Regression Paths & SRW* & SE & $\mathbf{T}$ & $\mathbf{P}$ & Decision \\
\hline $\mathrm{H} 1$ & Response time & $\mathrm{RT} \rightarrow \mathrm{CS}$ & .439 & .065 & 6.682 & .000 & Supported \\
\hline $\mathrm{H} 2$ & $\begin{array}{c}\text { Complaint resolution } \\
\text { perfection }\end{array}$ & $\mathrm{CRP} \rightarrow \mathrm{CS}$ & .424 & .060 & 6.951 & .000 & Supported \\
\hline $\mathrm{H} 3$ & $\begin{array}{l}\text { Responsiveness to } \\
\text { complaint }\end{array}$ & $\mathrm{RTC} \rightarrow \mathrm{CS}$ & .196 & .066 & 3.287 & .001 & Supported \\
\hline $\mathrm{H} 4$ & $\begin{array}{l}\text { Customer relations \& } \\
\text { executives attitude }\end{array}$ & CREA $\rightarrow$ CS & -.071 & .067 & -1.029 & .305 & Not Supported \\
\hline $\mathrm{H} 5$ & Brand image & $\mathrm{BI} \rightarrow \mathrm{CS}$ & .056 & .029 & 1.796 & .074 & Not Supported \\
\hline $\mathrm{H} 6$ & Customer satisfaction & $\mathrm{CS} \rightarrow \mathrm{CL}$ & .780 & .043 & 17.534 & .000 & Supported \\
\hline
\end{tabular}

\section{Conclusions}

The aim of this study was to investigate the antecedents of the customer satisfaction and customer loyalty, which triggers the economic aspects of business operation in the perspective of customer complaint handling for the airline industry. Based on the outcomes of the undertaken research, it is concluded that the response time, complaint resolution perfection, and responsiveness to the complaint have a positive and significant impact on the customer satisfaction and customer loyalty leading to the future economic aspects of business operation of the airline industry. This outcome is consistent with the previous literature pertaining to the effectiveness of response time to the customer complaint handling in the airline industry (Dudek et al., 2019; Lee, 2017; Mattila, 2006; Davidow, 2003; Wever, 2016; Park et al., 2005, 2006; Fornell, 1992; Blodgett et al., 1995; Gummesson, 1994). Explaining and analysing customer complaint handling based on the holistic approach, timely response and resolution of customer complaints can enhance the customer satisfaction, their loyalty, and future economic aspects of business operation in the airline industry. However, customer relations \& executives' attitude and image brand do not influence the customer satisfaction and loyalty among customers. Suchstudies as Chen and Jai (2019), and Gustafsson et al. (2005) show that higher responsibility lies on top management. It is for them to manage and maintain the existing customer satisfaction level and build value to attract customers. According to Moon et al. (2019), and Homburg and Furst (2005), the customer satisfaction can only be attained through instant solutions of their complaints that also enhance the customer loyalty and future economic aspects of business operation in the airline industry. The outcomes of the research further demonstrated that the customer satisfaction led to the customer loyalty. These results are also in line with the previous literature demonstrating that a high level of the customer satisfaction brings the customer loyalty in the 
airline industry (Alrawadieh et al., 2019; Zeithaml, 2000; Majumdar, 2005; Cronin \& Taylor, 1992; Gummesson, 1994; Fornell et al., 1996; Anderson et al., 1994). Complaints are not an essential factor for achieving the customer loyalty because complaints are just statements; though, addressing and resolving the customer complaints are paramount to attain the customer satisfaction, loyalty, and future economic aspects of business operation of the airline industry. Previous literature demonstrated that engaging customers and complaints should be taken as feedback to improve the organizational performance (Augusto et al., 2019; Yao et al., 2019). Moreover, the airline industry should solve customer complaints immediately and add augmented features in their services and products to gain long-term sustainability (Heymann,
2019). Thus, complaint handling could be considered as a marketing tool that can generate value addition to customers for long-term loyalty and future economic aspects of business operation in perspective of the airline industry.

Limitations of the study and directions for further research. The paper presents the study conducted in Pakistan, but the respondents involved in it have experience of traveling with various airlines, as all major airlines operating from Pakistan are such as "British Airways", "China Air", "The Emirates Airline", "Qatar Airline", etc. Thus, respondents have experience of traveling with all major airlines and using the services they provide. However, this study may reflect general airline services in handling passenger complaints. However, future research studies could also be conducted on more than one country or region.

\section{Disclosure Statement}

The authors have not reported any hindering conflict of interest.

\section{Acknowledgement}

We acknowledge the support of Indus University that provided during this project including administrative and technical support.

Appendix 1. Questionnaire

\begin{tabular}{|c|c|c|}
\hline & Statement & Reference \\
\hline $\begin{array}{l}\text { CL1 } \\
\text { CL2 } \\
\text { CL3 } \\
\text { CL4 }\end{array}$ & $\begin{array}{l}\text { I will prefer to use the services of this airline in the future } \\
\text { Compared to my friends, I do not replace the airline with a new one } \\
\text { Quality of service of the airline is the major binding force } \\
\text { Overall services of the airline inspired me to be intact with the airline }\end{array}$ & $\begin{array}{l}\text { Customer loyalty adapted } \\
\text { from Metwally (2013) \& So } \\
\text { et al. }(2014)\end{array}$ \\
\hline $\begin{array}{l}\text { CS1 } \\
\text { CS2 } \\
\text { CS3 } \\
\text { CS4 }\end{array}$ & $\begin{array}{l}\text { The value of money is equal to the services provided by the airline } \\
\text { I explore enjoyment and new dimensions of airline services } \\
\text { The amount and quality of food is sufficient } \\
\text { The overall services of the airline are beyond my imagination }\end{array}$ & $\begin{array}{l}\text { Customer satisfaction } \\
\text { modified from Chan (2014) } \\
\text { \& So et al. (2014) }\end{array}$ \\
\hline $\begin{array}{l}\text { RT1 } \\
\text { RT2 } \\
\text { RT3 } \\
\text { RT4 }\end{array}$ & $\begin{array}{l}\text { The response time of staff is swift to respond my complaints } \\
\text { The response time of the airline is quicker than my expectations } \\
\text { I do not have any problem while registering my complaints } \\
\text { In general, the response time of the crew and ground staff is very quick }\end{array}$ & $\begin{array}{l}\text { Response Time adapted from } \\
\text { Metwally (2013) }\end{array}$ \\
\hline $\begin{array}{l}\text { CRP1 } \\
\text { CRP2 } \\
\text { CRP3 } \\
\text { CRP4 }\end{array}$ & $\begin{array}{l}\text { The airline is capable to resolve complaints in a refined manner } \\
\text { The ground staff is handling \& resolving complaints in a perfect manner } \\
\text { The crew of the airline is highly skilled to respond to my complaints } \\
\text { In general, the airline is capable enough to resolve complaints in a professional and } \\
\text { comprehensive way }\end{array}$ & $\begin{array}{l}\text { Customer Resolution } \\
\text { Perfection modified from So } \\
\text { et al. }(2014) \text { \& Chan (2014) }\end{array}$ \\
\hline $\begin{array}{l}\text { CREA1 } \\
\text { CREA2 } \\
\text { CREA3 }\end{array}$ & $\begin{array}{l}\text { I intend to rebuy and continue using current service due to relationship with staff } \\
\text { The attitude of executives strengthens the customer-airline relationship } \\
\text { The executives' attitude enhances the overall quality of services due to timely } \\
\text { response to complaints handling }\end{array}$ & $\begin{array}{l}\text { Customer relationship \& } \\
\text { Executives' attitude adapted } \\
\text { from Chan (2014) }\end{array}$ \\
\hline $\begin{array}{l}\mathrm{BI} 1 \\
\mathrm{BI} 2 \\
\mathrm{BI} 3 \\
\mathrm{BI} 4\end{array}$ & $\begin{array}{l}\text { The image of the airline service is very similar to the kind of person I am } \\
\text { The image of a this airline is highly consistent with how I see myself } \\
\text { I would recommend to the friends/family due to the best services } \\
\text { The overall image of this airline exceeds my expectations }\end{array}$ & $\begin{array}{l}\text { Brand Image modified from } \\
\text { Metwally (2013) \& So et al. } \\
\text { (2014) }\end{array}$ \\
\hline $\begin{array}{l}\text { RTC1 } \\
\text { RTC2 } \\
\text { RTC3 } \\
\text { RTC4 }\end{array}$ & $\begin{array}{l}\text { The response time to handle complaints is very speedy \& rapid } \\
\text { I would appreciate the ground staff of the airline for responsiveness } \\
\text { I am happy to see the rapid efforts of crew to solve complaints } \\
\text { In general, the airline is very swift to respond to complaints }\end{array}$ & $\begin{array}{l}\text { Responsiveness to complaint } \\
\text { adapted from Chan (2014) \& } \\
\text { Metwally (2013) }\end{array}$ \\
\hline
\end{tabular}

Source: So et al. (2014), Chan (2014) \& Metwally (2013)

\section{References}

Ahmed, R. R., Vveinhardt, J., \& Streimikiene, D. (2019). Application of the Theory of Planned Behaviour Model for Examining Customers' Intentions towards Islamic Hire Purchase Financing. Inzinerine Ekonomika-Engineering Economics, 30(2), 236-245. https://doi.org/10.5755/j01.ee.30.2.21589 
Rizwan Raheem Ahmed, Jolita Vveinhardt, Usman Ali Warraich, Syed Shabib ul Hasan, Akhtar Baloch. Customer Satisfaction...

Alrawadieh, Z., Prayag, G., Alrawadieh, Z., \& Alsalameen, M. (2019). Self-identification with a heritage tourism site, visitors' engagement and destination loyalty: the mediating effects of overall satisfaction. The Service Industries Journal, 39(7-8), 541-558. https://doi.org/10.1080/02642069.2018.1564284

Anderson, E. W., Fornell, C., \& Lehmann, D. R. (1994). Customer satisfaction, market share, and profitability: findings from Sweden. The Journal of Marketing, 58(3), 53-66. https://doi.org/10.2307/1252310

Andreassen, T. W., \& Lindestad, B. (1998). Customer loyalty and complex services: the impact of corporate image on quality, customer satisfaction and loyalty for customers with varying degrees of service expertise. International Journal of Service Industry Management, 9(1), 7-23. https://doi.org/10.1108/09564239810199923

Augusto, M., Godinho, P., \& Torres, P. (2019). Building customers' resilience to negative information in the airline industry. Journal of Retailing and Consumer Services, 50, 235-248. https://doi.org/10.1016/j.jretconser.2019.05.015

Blodgett, J. G., Wakefield, K. L., \& Barnes, J. H. (1995). The Effects of Customer Service on Consumer Complaining Behaviour. Journal of Service Marketing, 9(4), 31-42. https://doi.org/10.1108/08876049510094487

Byrne, B. M. (2013). Structural equation modelling with AMOS, basic concepts, application and programming. 2nd Ed. New Jersey: La Erlbaum Associates. https://doi.org/10.4324/9780203805534

Cambra-Fierro, J., \& Melero-Polo, I. (2017). Complaint-handling as antecedent of customer engagement: do consumer characteristics matter? Marketing Intelligence \& Planning, 35(2), 277-295. https://doi.org/10.1108/MIP-02-20160039

Chan, J. K. L. (2014). Understanding the meaning of low airfare and satisfaction among leisure air travellers using Malaysian low-cost airlines. Journal of Vacation Marketing, 20(3), 211-223. https://doi.org/10.1177/ 1356766713519635

Chen, H. S., \& Jai, T. M. (2019). Trust fall: data breach perceptions from loyalty and non-loyalty customers. The Service Industries Journal, 1-17. https://doi.org/10.1080/02642069.2019.1603296

Chow, C. K. W., \& Tsui, W. H. K. (2017). Organizational learning, operating costs and airline consolidation policy in the Chinese airline industry. Journal of Air Transport Management, 63, 108-118. https://doi.org/10.1016/ j.jairtraman.2017.06.018

Clemes, M. D, Gan, C., Kao, T. H., \& Choong, M. (2008). An Empirical Analysis of Customer Satisfaction in International Air Travel. Innovative Marketing, 4(2), 49-63.

Clemes, M. D., Mollenkoph, D., \& Burn, D. (2000). An investigation of marketing problems across service typologies. Journal of Services Marketing, 14(7), 573-594. https://doi.org/10.1108/08876040010352754

Connor, D., \& Davidson, J. (1997). Marketing Your Consulting and Professional Services. John Wiley and Sons, New York

Cronin, J. J., Taylor, S. A. (1992). Measuring service quality: a reexamination and extension. Journal of Marketing, 56(3), 55-68. https://doi.org/10.2307/1252296

Daetz, D., Bernard, B. \& Rick, N. (1995). Customer Integration. John Wiley and Sons, USA.

Davidow, M. (2003). Organizational Responses to Customer Complaints: What Works and What Doesn't. Journal of Service Research, 5(3), 225-250. https://doi.org/10.1177/1094670502238917

Dennet, C. E., Ineson, M., Stone, G. J., \& Colgate, M. (2000). Pre-Bookable Services in the Chartered Airline Industry: Increasing Satisfaction through Differentiation. The Service Industries Journal, 20(2), 82-94. https://doi.org/10. 1080/02642060000000021

Dudek, A., Jaremen, D. E., Michalska-Dudek, I., Walesiak, M. (2019). Loyalty Model Proposal of Travel Agency Customers. Sustainability, 11(13), 3702. https://doi.org/10.3390/su11133702

Dwikesumasari, P. R., \& Ervianty, R. M. (2017). Customer Loyalty Analysis of Online Travel Agency App with Customer Satisfaction as A Mediation Variable. Conference Paper published 2017 in Proceedings of the 2017 International Conference on Organizational Innovation (ICOI 2017). https://doi.org/10.2991/icoi-17.2017.18

Emory, C. W., \& Cooper, D. R. (1991). Business Research Methods. (4th Ed.). Boston, MA: Irvin.

Estelami, H. (2000). Competitive and Procedural Determinants of Delight and Disappointment in Consumer Complaint Outcomes. Journal of Service Research, 2(3), 285-300. https://doi.org/10.1177/109467050023006

Etemad-Sajadi, R., \& Bohrer, L. (2019). The impact of service recovery output/process on customer satisfaction and loyalty: The case of the airline industry. Tourism and Hospitality Research, 19(2), 259-266. https://doi.org/10.1177/ 1467358417743080

Fecikova, I. (2004). An index method for measurement of customers' satisfaction. TQM Magazine, 16(1), 57-66. https://doi.org/10.1108/09544780410511498

Fornell, C. (1992). A National Customer Satisfaction Barometer: The Swedish Experience. Journal of Marketing, 56(1), 621. https://doi.org/10.1177/002224299205600103 
Fornell, C., \& Larcker, D. F. (1981). Evaluating Structural Equation Models with Unobservable Variables and Measurement Error. Journal of Marketing Research, 18(1), 39-50. https://doi.org/10.1177/002224378101800104

Fornell, C., Johnson, M. D., Anderson, E. W., Cha, J., \& Bryant, B. E. (1996). The American Customer Satisfaction Index: Nature, Purpose and Findings. Journal of Marketing, 60(4), 7-18. https://doi.org/10.2307/1251898

Fullerton, G. (2003). When Does Commitment Lead to Loyalty? Journal of Service Research, 5(4), 333-344. https://doi.org/10.1177/1094670503005004005

Gomez, B. G., Arranz, A. G., \& Cillan, J. G. (2006). The role of loyalty programs in behavioural and affective loyalty. Journal of Consumer Marketing, 23(7), 387-396. https://doi.org/10.1108/07363760610712920

Goodwin, C. C., \& Ross, I. (1992). Consumer responses to service failures: Influence of procedural and interactional fairness perceptions. Journal of Business Research, 25(2), 149-163. https://doi.org/10.1016/0148-2963(92)90014-3

Gummesson, E. (1994). Making Relationship Marketing Operational. International Journal of Service Industry Management, 5(5), 5-20. https://doi.org/10.1108/09564239410074349

Gustafsson, A., Johnson, M. D., \& Roos, I. (2005). The Effects of Customer Satisfaction, Relationship Commitment Dimensions, and Triggers on Customer Retention. Journal of Marketing, 69(4), 210-218.https://doi.org/10.1509/ jmkg.2005.69.4.210

Hair, J. F., Black, W. C., Babin, B. J., \& Anderson, R. E. (2010). Multivariate Data Analysis. Seventh Edition. Prentice Hall, Upper Saddle River, New Jersey.

Heymann, M. (2019). The changing value equation: Keeping customers satisfied while meeting bottom-line objectives in the service industry. Global Business and Organizational Excellence, 38(6), 24-30. https://doi.org/10.1002/ joe. 21964

Homburg, C., \& Furst, A. (2005). How organizational complaint handling drives customer loyalty: an analysis of the mechanistic and the organic approach. Journal of Marketing, 69(3), 95-114. https://doi.org/10.1509/jmkg. 69.3.95.66367

Iriqat, R. A. M., \& Abu-Daqar, M. A. M. (2017). The Impact of Customer Relationship Management on Long-term Customers' Loyalty in the Palestinian Banking Industry. International Business Research, 10(11), $139-147$. https://doi.org/10.5539/ibr.v10n11p139

Johnson, M. D., Gustafsson, A., Andreassen, T. W., Lervik, L., \& Cha, J. (2001). The evolution and future of national customer satisfaction index models. Journal of Economic Psychology, 22(2), 217-245. https://doi.org/10.1016/ S0167-4870(01)00030-7

Kaiser, H. F. (1974). An index of factorial simplicity. Psychometrika, 39(1), 31-36. https://doi.org/10.1007/BF02291575

Karamata, E., Chroneos-Krasavac, B., \& Soldic-Aleksic, J. (2017). Marketing implications of loyalty programs on customer relationship management within the airline industry. Marketing, 48(1), 30-40. https://doi.org/10.5937/ markt1701030K

Karande, K., \& Magnini, V. P. (2010). The Relative Use of Contextual and Temporal Reference Price Components in Hotel and Airline Purchases. Journal of Hospitality \& Tourism Research, 35(1), 119-141. https://doi.org/10.1177/109634 8010384477

Kloppenborg, T. J., \& Gourdin, K. N. (1992). Up in the Air about Quality. Quality Progress, 25(2), 31-35.

Law, C. (2017). The study of customer relationship management in Thai airline industry: A case of Thai travellers in Thailand. Journal of Airline and Airport Management, 7(1), 13-42. http://dx.doi.org/10.3926/jairm.86

Lee, M., \& Cunningham, L. F. (1996). Customer Loyalty in the Airline Industry. Transportation Quarterly, 50(2), 57-72.

Lee, M. J. (2017). The influence of corporate social responsibility on customer-company identification and customer loyalty in the airline industry. International Journal of Tourism and Hospitality Research, 31(1), 123-136. doi:10.21298/ijthr.2017.01.31.1.123

Majumdar, A. (2005). A model for customer loyalty for retail stores inside shopping malls - an Indian perspective. Journal of Services Research, Special Issue (December), 47-64.

Mattila, A. (2006). How Affective Commitment Boosts Guest Loyalty (and Promotes Frequent-guest Programs). Cornell Hospitality Quarterly, 47(2), 174-181. https://doi.org/10.1177/0010880405283943

Metwally, D. (2013). Complaint Handling in the Airline Industry: The Way to Enhance Customer Loyalty. Mediterranean Journal of Social Sciences, 4(10), 299-311. 10.5901/mjss.2013.v4n10p299

Michel, S. (2001). Analyzing service failures and recoveries: a process approach. International Journal of Service Industry Management, 12(1), 20-33. https://doi.org/10.1108/09564230110382754

Moon, H., Wei, W., \& Miao, L. (2019). Complaints and resolutions in a peer-to-peer business model. International Journal of Hospitality Management, 81, 239-248. https://doi.org/10.1016/j.ijhm.2019.04.026 
Rizwan Raheem Ahmed, Jolita Vveinhardt, Usman Ali Warraich, Syed Shabib ul Hasan, Akhtar Baloch. Customer Satisfaction...

Nguyen, N., \& LeBlanc, G. (2001). Image and reputation of higher education institutions in students' retention decisions. International Journal of Educational Management, 15(6), 303-311. https://doi.org/10.1108/EUM0000000005909

Oliver, R. (1997). Satisfaction: A Behavioural Perspective of the Consumer. McGraw-Hill, New York, NY.

Ostrowski, R. L., O'Brien T. V., \& Gordon, G. L. (1993). Service quality and customer loyalty in the commercial airline industry. Journal of Travel Research, 32(2), 16-24. https://doi.org/10.1177/004728759303200203

Oyewole, P., Sankaran, M., \& Choudhury, P. (2007). Marketing Airline Services in Malaysia: A Consumer Satisfaction Orientation Approach. Innovative Marketing, 3(1), 56-70.

Parasuraman, A., Zeithaml, V.A., \& Berry, L.L. (1985). A conceptual model of service quality and its implication. The Journal of Marketing, 49(Fall), 41-50. https://doi.org/10.2307/1251430

Park, J. W., Robertson, R., \& Wu, C. L. (2005). Investigating the effects of airline service quality on airline image and passengers' future behavioral intentions: finding from Australian International air passengers. Journal of Tourism Studies, 16(1), 2-11.

Park, J. W., Robertson, R., \& Wu, C. L. (2006). The Effects of Individual Dimensions of Airline Service Quality: Findings from Australian Domestic Air Passengers. Journal of Hospitality and Tourism Management, 13(2), 161-176. https://doi.org/10.1375/jhtm.13.2.161

Prentice, C., Maria, S., \& Loureiro, C. (2017). An asymmetrical approach to understanding configurations of customer loyalty in the airline industry. Journal of Retailing and Consumer Services, 38, 96-107. https://doi.org/10.10 16/j.jretconser.2017.05.005

Servera-Frances, D., \& Piqueras-Tomas, L. (2019). The effects of corporate social responsibility on consumer loyalty through consumer perceived value. Economic Research-Ekonomska Istrazivanja, 32(1), 66-84. https://doi.org/10. 1080/1331677X.2018.1547202

Shin, D., \& Elliott, K. (2001). Measuring Customer Overall Satisfaction: A Multi-Attributes Assessment Services. Marketing Quarterly, 22(1), 3-19. https://doi.org/10.1300/J396v22n01_02

Smirnov, V. (2019). Aspects of Bank Customers Ensuring Loyalty. Bulletin of Science and Practice, 5(6), $286-286$. https://doi.org/10.33619/2414-2948/43/36

Smith, A. K., Bolton, R. N., \& Wagner, J. (1999). A model of customer satisfaction with service encounters involving failure and recovery. Journal of Marketing Research, 36(3), 356-372. https://doi.org/10.2307/3152082

So, K. K. F., King, C., Sparks, B. A., \& Wang, Y. (2014). The Role of Customer Engagement in Building Consumer Loyalty to Tourism Brands. Journal of Travel Research, 55(1), 64-78. https://doi.org/10.1177/0047287514541008

Vilkaite-Vaitone, N., \& Papsiene, P. (2016). Influence of Customer Loyalty Program on Organizational Performance: a Case of Airline Industry. Inzinerine Ekonomika-Engineering Economics, 27(1), 109-116. https://doi.org/10.5755/ j01.ee.27.1.10267

Wever, M. (2016). The Importance of Customer Loyalty Programs for the European Airline Industry. Journal of US-China Public Administration, 13(1), 55-70. doi: 10.17265/1548-6591/2016.01.006

Wirtz, J., \& Mattila, A. S. (2004). Consumer responses to compensation, speed of recovery and apology after a service failure. International Journal of Service Industry Management, 15(2), 150-166. https://doi.org/10.1108/09564 230410532484

Wu, L. W. (2011). Satisfaction, inertia, and customer loyalty in the varying levels of the zone of tolerance and alternative attractiveness. Journal of Service Marketing, 25(5), 310-322. https://doi.org/10.1108/08876041111149676

Yao, T., Qiu, Q., \& Wei, Y. (2019). Retaining hotel employees as internal customers: Effect of organizational commitment on attitudinal and behavioral loyalty of employees. International Journal of Hospitality Management, 76, 1-8. https://doi.org/10.1016/j.ijhm.2018.03.018

Zeelenberg, M., \& Pieters, R. (2004). Beyond valence in customers' dissatisfaction: a review and new findings on behavioral response to regret and disappointment in failed services. Journal of Business Research, 57(4), 445-455. https://doi.org/10.1016/S0148-2963(02)00278-3

Zeithaml, V. A. (2000). Service Quality, Profitability, and the Economic worth of Customers: What we know and what we don't know. Journal of the Academy of Marketing Science, 28(1), 67-85. https://doi.org/10.1177/0092070300281007

The article has been reviewed.

Received in October 2018; accepted in February 2020. 